\title{
Species diversity, dominance and equitability in tropical dry deciduous forest of Bundelkhand region, India
}

\begin{abstract}
The tropical Dry deciduous forests of Bundelkhand region are under tremendous pressure of biotic interferences and climate change. There has been significant reduction in rainfall of the area due to climate change. The increase in intensity and frequency of droughts could lead the forests to lose their self- maintenance capabilities against the changes already brought in due to biotic interferences. Present investigation has under taken aims to assess the phyto-sociological analysis i.e. species diversity, dominance and equitability, etc. of three different forest of Lalitpur, Mahoba and Chitrakoot district of Bundelkhand region of Uttar Pradesh, India. The forest of Mahoba district is dominated by Anogeissus pendula and Butea monosperma, having forest of Chitrakoot district is dominated by Diospyrous melanoxylon and Lagerstromia parviflora whereas forest of Lalitpur district is dominated by Butea monosperma and Tectona grandis. Result indicates that there was higher species diversity of trees in B. monosperma and T. grandis dominated Lalitpur district forest (3.6556) to be followed by $A$. pendula and B. monosperma dominated Mahoba district forest (3.6535) and D. melanoxylon and L. parviflora dominated Chitrakoot district forest (3.5039). Mahoba district forest exhibited higher values of concentration of Dominanc (0.970854) to be followed by Lalitpur district forest (0.967797) and Chitrakoot district forest (0.963256). Mahoba district forest showed higher values of Eqitability (0.9339) to be followed by Lalitpur district forest (0.8928) and Chitrakoot district forest (0.8784).
\end{abstract}

Volume 3 Issue 4 - 2019

\author{
Manish Verma, Amit Pal \\ Institute of Environment \& Development Studies, Bundelkhand \\ University, India
}

Correspondence: Amit Pal, Institute of Environment \& Development Studies, Bundelkhand University, JHANSI - 284 128, India, Email apu I3@rediffmail.com

Received: February 04, 2019 | Published: July 22, 2019

Keywords: Bundelkhand region, chitrakoot, lalitpur, mahoba, butea monosperma, tectona grandis

\section{Introduction}

India is a large developing country known for its diverse forest ecosystems and is also a mega-biodiversity nation of the World. Forest ecosystems in India are critical for biodiversity, watershed protection and livelihoods of indigenous and rural communities. India is a country with a high population density and low forest area per capita. The livestock population density is among the highest in the world. Further, nearly $70 \%$ of the population residing in rural areas depends on forest and other biomass resources for fuel-wood, timber and nontimber forest products for its energy needs and livelihood. Fuel-wood is a dominant source of cooking energy for the Ethnic population with forests contributing significantly to this. Forests are repository of the biodiversity, gene pool resources, sequester carbon dioxide and provide lot of other environmental services. They play a vital role in sustaining the life of people and are crucial for the food and water security. The first and foremost objective of forest management in any country is to ensure livelihood security. This is ensured through better management practices and sustainable utilization of forestlands. ${ }^{1}$ Forests supply nutrients to agricultural crops through runoff water with much other complementariness in agriculture ecosystems. ${ }^{2}$ In the absence of operation planning and convergence degradation of forests and adjoining lands continued which seriously affected the sustainability of crops and natural vegetation. Due to continuous degradation of land resources, depletion of precious biodiversity and conservation functions of forests the resource is getting reduced gradually causing serious ecological concerns in many parts of the country. ${ }^{3}$ As forests disappeared, the possibilities of natural resources being conserved decreased and the possibilities of conservation also decreased. The tropical Dry deciduous forests of Bundelkhand region are under tremendous pressure of biotic interferences and climate change. There has been significant reduction in rainfall of the area due to climate change. The increase in intensity and frequency of droughts could lead the forests to lose their self maintenance capabilities against the changes already brought in due to biotic interferences. An obvious approach to conserve plant biodiversity is to map distributional patterns and look for concentrations of diversity. Further, management of forest requires understanding of its composition in relation to other forests. On this background the present study has under taken aims to assess the phyto-sociological analysis i.e. species diversity, dominance and equitability, etc. of three different forest of Lalitpur, Mahoba and Chitrakoot district of Uttar Pradesh, India which are belongs to Tropical Dry Deciduous Forest. ${ }^{4}$

\section{Materials and methods}

\section{Study area}

Bundelkhnad region of Uttar Pradesh is having $29,418 \mathrm{Km}^{2}$ of geographical area and only $6.61 \%$ its forest which is rich in dry deciduous mixed in nature. Present investigations have been carried out in selected forest of three districts of Bundelkhnad region (Figure 1) namely Lalitpur, Mahoba and Chitrakoot for their phytosociological attributes (e.g. density, dominance, similarity of species between forest communities, etc.) of plant communities.

\section{Vegetation analysis}

The surveys of area have been done by sampling method. Size of the unit sample (quadrate) and minimum number of samples have been determined by species-area curve and minimum quadrate-number 
method, respectively. Analytical characters were obtained mostly by vegetation analysis with the help of nested quadrate method. The quadrate size for trees, shrubs, and herbs was $10 \mathrm{~m} \times 10 \mathrm{~m}, 3 \mathrm{~m} \times 3 \mathrm{~m}$ and $1 \mathrm{mx} 1 \mathrm{~m}$ respectively.

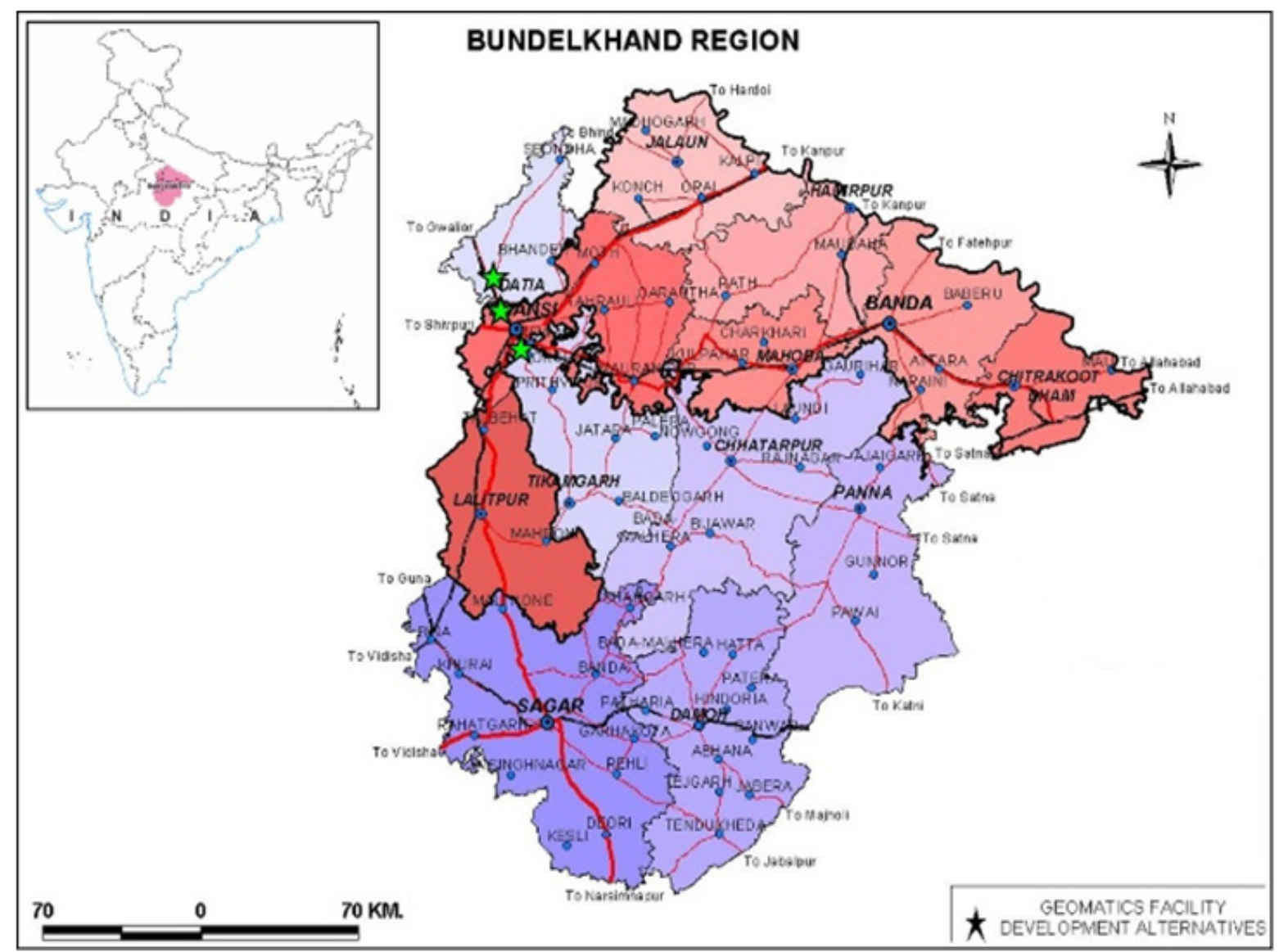

Figure I Bundelkhand region of India.

[Source: http://www.taragramyatra.org/TARAGRAM.aspx]

\section{Phytosociological study}

The term vegetation ecology is also equated to phytosociology or community ecology. Trees and ground vegetation were differentiated by measuring the girth at breast height (gbh). ${ }^{5}$ Only stems $\geq 20 \mathrm{~cm}$ gbh $(1.3 \mathrm{~m}$ above ground level) were considered "woody trees" and phytosociological analyses were limited to them. Girth was measured using $2 \mathrm{~m}$ tape. Height of small trees and shrubs was measured using a $5 \mathrm{~m}$ graded pole. When the height exceeded $5 \mathrm{~m}$ it was estimated visually. For calculating the basal area of multi-stemmed trees, the girth of each stem was measured individually and added up phytosociological parameters were analyzed the following the methods and formulas. ${ }^{6}$

\section{Species diversity analysis}

Species diversity was calculated using the Simpson index ${ }^{7}$ and Shannon-Wiener index. ${ }^{8}$ The pooled data of important value index were used to calculate the species richness and general diversity in selected forest of Bundelkhand region.

\section{Equitability or evenness}

The equitability (range $0-1$ ) is found by the following formula:

$E=H / \log s$

Where, $\log \mathrm{s}=$ value of species diversity index under condition of maximal equitability.

\section{Similarity index}

The mathematical expressions of community similarity are variously referred as indices of similarity. The similarity of plant species of forest was determined according to Sorenson. ${ }^{9}$

\section{Results and discussions}

It is obvious from this study that out of three forest communities of trees the forest of Mahoba district is dominated by Anogeissus pendula and Butea monosperma, forest of Chitrakoot district is dominated by Diospyrous melanoxylon and Lagerstromia parviflora whereas forest of Lalitpur district is dominated by Butea monosperma and Tectona grandis. 
A Forest community of shrubs/herbs/climbers in Mahoba district forest is dominated by Flacourtia indica and Zizyphus nummularia whereas forest communities of shrubs/herbs/climbers in Chitrakoot and Lalitpur district forest is dominated by Flacourtia indica and Zizyphus mauritiana. The B. monosperma and T. grandis dominated tree forest community of Lalitpur district forest is composed of maximum number of 59 tree species and 40 shrubs/herbs/climbers species followed by D. melanoxylon and L. parviflora dominated tree forest community of Chitrakoot district forest is composed of 54 tree species and $38 \mathrm{shrubs} / \mathrm{herbs} / \mathrm{climbers}$ species and $A$. pendula and $B$. monosperma dominated tree forest community of Mahoba district forest is composed of 50 tree species and 31 shrubs/herbs/climbers species. It is also evident from the result that the dominance of these forest communities is shared by only few species whereas majority of trees and shrubs/herbs/climbers species are with lower values of IVI.

Total density plant per $100 \mathrm{~m}^{2}$ of different tree species and shrubs/herbs/climbers species have been determine for three forest communities (Table 1). Result reveals that there was higher density of trees is the Lalitpur forest followed by Chitrakoot and Mahoba district forest whereas higher density of shrubs/herbs/climbers is the Lalitpur district forest followed by Chitrakoot and Mahoba district forest (Table 2).

Table I Total density (plant $\left./ 100 \mathrm{~m}^{2}\right)$ and Basal Area $\left(\mathrm{m}^{2} / \mathrm{ha}\right)$ of tress of three forest communities

\begin{tabular}{lll}
\hline Forest & Total density & Total basal area \\
\hline Lalitpur district forest & 7.15 & 59.784 \\
Chitrakoot district forest & 6.53 & 48.352 \\
Mahoba district forest & 5.88 & 41.365
\end{tabular}

Table 2 Total density (plant/100 $\left.\mathrm{m}^{2}\right)$ and basal area $\left(\mathrm{m}^{2} / \mathrm{ha}\right)$ of shrubs/herbs/ climbers of three forest communities

\begin{tabular}{lll}
\hline Forest & Total density & Total basal area \\
\hline Lalitpur district forest & 49.21 & 1.523 \\
Chitrakoot district forest & 46.88 & 1.63 \\
Mahoba district forest & 39.22 & 1.184 \\
\hline
\end{tabular}

Plants species Diversity $\left(H^{\prime}\right)$, concentration of Dominance (D) and Equitability (E) of three forest communities have been presented in the Tables $3 \& 4$. Result indicates that there was higher species diversity of trees in B. monosperma and $T$. grandis dominated Lalitpur district forest (3.6556) to be followed by $A$. pendula and $B$. monosperma dominated Mahoba district forest (3.6535) and D. melanoxylon and L. parviflora dominated Chitrakoot district forest (3.5039). Mahoba district forest exhibited higher values of concentration of Dominanc $(0.970854)$ to be followed by Lalitpur district forest $(0.967797)$ and Chitrakoot district forest (0.963256). Mahoba district forest showed higher values of Eqitability (0.9339) to be followed by Lalitpur district forest (0.8928) and Chitrakoot district forest (0.8784). Result also indicates that there was higher species diversity of shrubs/ herbs/climbers in F. indica and Z. mauritiana dominated Lalitpur district forest (3.1952) to be followed by $F$. indica and $Z$. mauritiana dominated Chitrakoot district forest (3.1563) and $F$. indica and $Z$. nummularia dominated Mahoba district forest (3.0028). Lalitpur district forest exhibited higher values of concentration of Dominanc (0.934721) to be followed by Mahoba district forest (0.930048) and Chitrakoot district forest (0.928583). Mahoba District Forest showed higher values of Eqitability ( 0.8744$)$ to be followed by Chitrakoot district forest (0.8677) and Lalitpur district forest (0.8662).

Results indicated that maximum similarity between tree species of Lalitpur and Mahoba forest communities (81.81\%) followed by Chitrakoot and Mahoba (Tables 5\&7) forest communities (78.84\%) and Lalitpur and Chitrakoot forest communities (77.19\%). Whereas maximum similarity between shrubs/herbs/climbers species (Tables 6\&8) of Lalitpur and Chitrakoot forest communities (97.43\%) followed by Lalitpur and Mahoba forest communities (84.50\%) and Chitrakoot and Mahoba forest communities (84.05\%). About 37 trees species are common in all the three forest communities and 29 shrubs/ herbs/climbers species are common in all the three forest communities.

The species richness of tree species were observed as 59 in Lalitpur District Forest, 54 in Chitrakoot District Forest and 50 in Mahoba Forest and shrub/herbs/climbers species have been observed as 40 in Lalitpur, 38 in Chitrakoot and 31 in Mahoba District Forest, ${ }^{10-12}$ in three forests are comparable with other forest communities of India. Rao et al., ${ }^{13}$ observed 61 tree and shrub species in tropical forest of Chitrakoot. 53 and 57 tree and shrub species have been reported for tropical semi-evergreen forest of Manipur, North-East India and tropical evergreen forest of Courtallum reserve forest of Western Ghats ${ }^{14,15}$ respectively. Tropical forests of Andaman Islands, ${ }^{16}$ Bala forest in Alwar of Rajasthan, ${ }^{17}$ Shivaliks, Doon Valley and outer Himalaya, ${ }^{18}$ have shown species richness in the range of present study. It is also nearly similar to the values obtained in some rainforest of Africa. ${ }^{19,20}$ However, the species richness of studied forest communities are lower than those reported for moist evergreen forest of Western Ghats of Karnataka (91 species), ${ }^{21}$ semi-evergreen forest of Kalrayan hills, Eastern Ghat $(73$ species $){ }^{22}$ south-eastern Asian evergreen forest of Sabah (198 species), ${ }^{23}$ for Sarawak (214 species) $)^{24}$ and for Peninsular Malaysia (244 species). ${ }^{25}$

These values of species richness have been found within the range of tropics i.e. 20-307 spp. ha ${ }^{-1}{ }^{26,27}$ These values of the species richness have been found lower in comparison with the humid tropical evergreen forest (61 species ha-1), ${ }^{28}$ but higher than the tropical rain forest (43 species ha $\left.{ }^{-1}\right){ }^{29}$ The species richness in the study area has been found higher than the tropical dry forests of Mirzapur (9-14), ${ }^{30}$ Similipal Biosphare Reserve (19-36) ${ }^{31}$ and tropical dry evergreen forest of Tanil Nadu (19-35) ${ }^{32,33}$ but lower than tropical dry deciduous forest of Andhra Pradesh (69) ${ }^{34}$ and tropical wet evergreen forest of Kalakad (80-85). ${ }^{35}$ More significantly, the mean species richness has been found greater than the earlier report from the area in which they have recorded only 44 tree species in 7.02 hectares. ${ }^{36}$

Total density (Plant $\left./ 100 \mathrm{~m}^{2}\right)$ of tree species have been observed as 7.15 plant $/ 100 \mathrm{~m}^{2}$ (Lalitpur District Forest), 6.53 plant $/ 100 \mathrm{~m}^{2}$ (Chitrakoot District Forest) and 5.88 plant $/ 100 \mathrm{~m}^{2}$ (Mahoba District Forest) and shrub/herbs/climbers species have been observed as 49.22 plant $/ 100 \mathrm{~m}^{2}$ (Lalitpur District Forest), 46.88 plant $/ 100 \mathrm{~m}^{2}$ (Chitrakoot District Forest) and 39.22 plant $/ 100 \mathrm{~m}^{2}$ (Mahoba District Forest). These values of tree density have been found within the range of tropics i.e. 276-935 stem ha ${ }^{-1} \cdot{ }^{33,37-39}$ The tree density in the sanctuary area has been found higher than the tropical evergreen forests of Western as well as Eastern Ghats where it ranges from 419-716 stem ha ${ }^{-135,39-42}$ and tropical deciduous forests $\left(150-627\right.$ stem ha $\left.^{-1}\right) .^{30,43-47}$ Tropical moist forest of Singapore (604 stem ha $\left.{ }^{-1}\right)^{48}$ and tropical rain forest of Costa Rica (391-617 stem ha $\left.{ }^{-1}\right)^{49}$ also have the lower tree density than that of the sanctuary area. Some tropical deciduous forest of Eastern Ghats ranging from 735-810 stem $\mathrm{ha}^{-1},{ }^{31,34}$ tropical evergreen forest 
of Eastern Ghats and North-East India ranging from 750-935 stem $\mathrm{ha}^{-133,50,51}$ and tropical rain forest of Amazon and Malaysia ranging from 1054-1420 stem ha ${ }^{-152,53}$ show the higher tree density than the sanctuary area.

The recorded stem densities of three forests are well within range of 245 to 859 stems ha ${ }^{-1}$ reported for trees in the tropics. ${ }^{54}$ However, the observed total densities $\left(\mathrm{ha}^{-1}\right)$ are lower when compared with $610-635$ stems ha $^{-1}$ in Uppangala sites of Karnataka, ${ }^{55} 482$ stem ha $^{-1}$ in tropical evergreen forest in Courtallum reserve forest of Western Ghats, ${ }^{15}$ 938-1476 stems ha- ${ }^{-1}$ in subtropical humid forest of North-east India, ${ }^{56} 1176-1496$ stems $^{\text {ha }}{ }^{-1}$ in subtropical humid forest of Jaintia hills of Meghalaya, ${ }^{57} 367$ to 667 stems ha $^{-1}$ in tropical semi-evergreen forest of Kalrayan hills, Eastern Ghats. ${ }^{22}$

The stem density in the present study is also average than other tropical forests such as those of Bolivia (649 trees ha $\left.{ }^{-1}\right),{ }^{58}$ Costa Rica (448-617 stems ha $\left.^{-1}\right),{ }^{49}$ and Lowland tropical forests in Kurupukari, Guayana (716-1440 stem ha-1). ${ }^{59}$ The values of total density in several other tropical forests ranged from 5.5 to 18 treesha $^{-1},{ }^{50}$ while for temperate forests, the same is ranged from 3.2 to 21 trees ha-1. ${ }^{60-63}$ The tree basal cover was measured as $59.784 \mathrm{~m}^{2} \mathrm{ha}^{-1}$ (Lalitpur Distric Forest), $48.352 \mathrm{~m}^{2} \mathrm{ha}^{-1}$ (Chitrakoot Forest) and $41.365 \mathrm{~m}^{2} \mathrm{ha}^{-1}$ (Mahoba Forest) and shrub/herbs/climbers species basal cover was measured as $1.523 \mathrm{~m}^{2} \mathrm{ha}^{-1}$ (Lalitpur Distric Forest), $1.630 \mathrm{~m}^{2} \mathrm{ha}^{-1}$ (Chitrakoot Forest) and $1.184 \mathrm{~m}^{2} \mathrm{ha}^{-1}$ (Mahoba Forest). These values of basal area have been found within the range of tropics i.e. $7-104 \mathrm{~m}^{2} \mathrm{ha}^{-1} \cdot 3^{11,40,43}$ The basal area has been found higher than the tropical evergreen forests ranging from $11-82.76 \mathrm{~m}^{2} \mathrm{ha}^{-129,33,42,50,51}$ and tropical deciduous forest ranging from $7-61 \mathrm{~m}^{2} \mathrm{ha}^{-1},{ }^{10,36,43,44,45}$ in India. The basal area of tropical rain forest of Malaysia i.e. $26-46 \mathrm{~m}^{2} \mathrm{ha}^{-1},{ }^{24}$ also has the lower basal area than the sanctuary area. The basal cover of some evergreen forests of Western Ghat ranging from 29-103 $\mathrm{m}^{2} \mathrm{ha}^{-1},{ }^{40,41}$ Similipal Biosphere Reserve 48.7-10.9 $\mathrm{m}^{2} \mathrm{ha}^{-1},{ }^{31}$ and the tropical rain forest of Amazonia 28 to $68 \mathrm{~m}^{2} \mathrm{ha}^{-1},{ }^{52}$ have been found higher than the forest of sanctuary area. More significantly, the basal area of the adjacent forests ranging from $16-61 \mathrm{~m}^{2} \mathrm{ha}^{-1},{ }^{36,45}$ has been found lower than the basal cover of the study area.

These values are lower to the tropical rain forest $\left(78 \mathrm{~m}^{2} \mathrm{ha} \mathrm{a}^{-1}\right)$ of Amazonia, ${ }^{52}$ tropical dry deciduous forest $\left(75.9 \mathrm{~m}^{2} \mathrm{ha}^{-1}\right)$ in Chitrakoot of Madhya Pradesh, ${ }^{13}$ tropical forests (12.44-77.4m² ha-1) of Andaman islands ${ }^{16}$ and subtropical humid forests $\left(36-71 \mathrm{~m}^{2} \mathrm{ha}^{-1}\right)$ in Maghalaya. ${ }^{56}$ However, the observed basal cover values under present study are higher than the moist evergreen forest $\left(39.7 \mathrm{~m}^{2} \mathrm{ha}^{-1}\right)$ in Western Ghats of Karnataka, ${ }^{21}$ tropical evergreen forest $\left(42.61 \mathrm{~m}^{2} \mathrm{ha}^{-1}\right)$ in Courtallum reserve forest, Western Ghats, ${ }^{15}$ sal forests $\left(23.24-37.75 \mathrm{~m}^{2} \mathrm{ha}^{-1}\right)$ in Doon valley, ${ }^{64}$ tropical semi-evergreen forest $\left(18.9-19.58 \mathrm{~m}^{2} \mathrm{ha}^{-}\right.$ $\left.{ }^{1}\right)$ in Manipur, north-east India, ${ }^{14}$ tropical semi-evergreen forest $\left(25.8-41.2 \mathrm{~m}^{2} \mathrm{ha}^{-1}\right)$ of Kalrayan hills, Eastern Ghats, ${ }^{22}$ tropical forests $\left(39.7 \mathrm{~m}^{2} \mathrm{ha}^{-1}\right)$ in Uppangala of Central Western Ghats. ${ }^{55}$

These forest communities have been also investigated in present study for their tree (Table 3 ) and shrub/herbs/climbers species diversity (Table 4). Results indicated that for tree species, B. monosperma and T. grandis dominated Lalitpur district forest exhibited higher species diversity $\left(H^{\prime}=3.6556\right)$ than $A$. pendula and $B$. monosperma dominated Mahoba district forest $\left(H^{\prime}=3.6535\right)$ and $D$. melanoxylon and $L$. parviflora dominated Chitrakoot district forest $\left(H^{\prime}=3.5039\right)$ and for shrub/herbs/climbers species, $F$. indica and Z. mauritiana dominated Lalitpur district forest exhibited higher species diversity $\left(H^{\prime}=3.1952\right)$ than F. indica and Z. mauritiana dominated Chitrakoot district forest $\left(H^{\prime}=3.1563\right)$ and $F$. indica and $Z$. nummularia dominated Mahoba district forest $\left(H^{\prime}=3.0028\right)$. Species diversity is one of the most important characteristics of a community. It is a mechanism which generates stability. ${ }^{65}$ Results indicate that there is a narrow variation in species diversity among these three forest community. The diversity of the three forests is positively related to the number of species. In a deciduous forest community, Monk ${ }^{66}$ observed that diversity tended to reach a maximum level after a community is composed of 12-15 species.

The species diversity values were reported between 1.16 to 3.40 for temperate forests. ${ }^{63,66-68}$ The diversity index is generally higher for tropical forests, which is reported as 5.06 and 5.40 for young and old stand respectively. ${ }^{69}$ The values of species diversity under present investigation are much less than those reported for tropical forests. ${ }^{69}$ However, these are comparable with the values generally reported for other tropical forests. ${ }^{64,70-72}$ The species diversity values of studied forests are average than those reported as 1.855 to 2.029 for Rampara forest in Saurastra, Gujrat, ${ }^{73} 3.42$ to 3.87 for subtropical humid forest, Meghalaya ${ }^{56} 3.069$ for tropical evergreen forest in Courtallum reserve forest of Western Ghatsm, ${ }^{15} 4.56$ for moist evergreen forest in Western Ghats ${ }^{21}$ and 2.305 to 2.869 for tropical semi evergreen forest of Kalrayen hills, Eastern Ghats. ${ }^{22}$ Some other forests of Madhya Pradesh such as Seoni, Balaghat and Mandla also exhibited higher species diversity than those of this study. ${ }^{74}$

The concentration of dominance for tree species on density basis was higher in Mahoba followed by Lalitpur and Chitrakoot district forest (Table 3) but the concentration of dominance for shrub/herbs/ climbers species on density basis was higher in Lalitpur followed by Mahoba and Chitrakoot district forest (Table 4). Risser and Rice ${ }^{67}$ have reported concentration of dominance values in the range of 0.10 to 0.99 for temperate vegetation. For a tropical forest, Knight ${ }^{69}$ reported an average value of 0.06 . The observed values under present investigation are higher than average value of tropical forests reported by Knight. ${ }^{69}$ There was a narrow variation in values obtained for three forests. The higher value of CD in Mahoba District forest could be attributed to the environmental stress. ${ }^{75}$ These relatively high values for concentration of dominance in this study than reported average value (0.06) of tropical forests are in accordance with low species diversity at the studied sites because species diversity $(H)$ behaves inversely to the index of dominance. ${ }^{76}$ The observed $C D$ values of studied forests are comparable with the value obtained (0.92) for moist evergreen forest of Western Ghats, ${ }^{21}$ but are higher to those of tropical evergreen forest in Courtallum reserve forest of Western Ghats ${ }^{15}$ and Rampura forest in Saurashtra, Gujarat. ${ }^{73}$

Dominance increases as a function of stress, ${ }^{77}$ due to past damage, ${ }^{78}$ poor drainage ${ }^{54}$ etc. Species represented by one or two individuals were considered rare. ${ }^{79}$ It is evident that many widespread tropical species tend to be locally abundant in certain areas and relatively rare in others..$^{80}$ The numbers of individuals of such rare species are kept low by a combination of unfavorable regeneration conditions, lack of appropriate habitat or both. ${ }^{81}$ In this respect also, the studied forests are similar to tropical forests, which are known to possess large number of tree species that have few individuals. However, with disturbance number of such species decreased as there was an increase in number of individuals of those species which are resistant to damage or to death caused by physical extremes or natural enemies that eventually fill much of the space after disturbances. ${ }^{82}$ 
Table 3 Species diversity, dominance and equitability of trees of three forest communities

\begin{tabular}{lllll}
\hline Forest & $\begin{array}{l}\text { Species } \\
\text { richness }(\mathbf{R})\end{array}$ & $\begin{array}{l}\text { Species diversity } \\
\left(\mathbf{H}^{\prime}\right)\end{array}$ & Equitability (E) & $\begin{array}{l}\text { Concentration of } \\
\text { dominance (D) }\end{array}$ \\
\hline Lalitpur district forest & 59 & 3.6556 & 0.8928 & 0.967797 \\
Chitrakoot district forest & 54 & 3.5039 & 0.8784 & 0.963256 \\
Mahoba district forest & 50 & 3.6535 & 0.9339 & 0.970854 \\
\hline
\end{tabular}

Table 4 Species diversity, dominance and equitability of shrubs/herbs/climbers of three forest communities

\begin{tabular}{lllll}
\hline Forest & $\begin{array}{l}\text { Species } \\
\text { richness (R) }\end{array}$ & $\begin{array}{l}\text { Species } \\
\text { diversity (H') }\end{array}$ & Equitability (E) & $\begin{array}{l}\text { Concentration of } \\
\text { dominance }\end{array}$ \\
\hline Lalitpur district forest & 40 & 3.1952 & 0.8662 & 0.934721 \\
Chitrakoot district forest & 38 & 3.1563 & 0.8677 & 0.928583 \\
Mahoba district forest & 31 & 3.0028 & 0.8744 & 0.930048
\end{tabular}

Table 5 Common tree species of three forest communities

\begin{tabular}{|c|c|c|c|}
\hline S No & Lalitpur-Chitrakoot forest & Chitrakoot-Mahoba forest & Lalitpur-Mahoba forest \\
\hline I & Acacia catechu & Acacia catechu & Acacia catechu \\
\hline 2 & Acacia leucophlaea & Acacia leucophlaea & Acacia leucophlaea \\
\hline 3 & Acacia nilotica & Acacia nilotica & Acacia nilotica \\
\hline 4 & Adina cardifolia & Adina cardifolia & Adina cardifolia \\
\hline 5 & Aegle marmelos & Aegle marmelos & Aegle marmelos \\
\hline 6 & Albizzia lebbek & Ailanthus excels & Alangium salvifolium \\
\hline 7 & Albizzia procera & Albizzia lebbek & Albizzia lebbek \\
\hline 8 & Anogeissus latifolia & Anogeissus latifolia & Albizzia odoretissima \\
\hline 9 & Anogeissus pendula & Anogeissus pendula & Anogeissus latifolia \\
\hline 10 & Azadirachta indica & Azadirachta indica & Anogeissus pendula \\
\hline II & Bauhinia racemosa & Bauhinia racemosa & Azadirachta indica \\
\hline 12 & Bombax ceiba & Buchanania lanzan & Bauhinia racemosa \\
\hline 13 & Boswellia serrata & Butea monosperma & Buchanania lanzan \\
\hline 14 & Buchanania lanzan & Carissa spinarum & Butea monosperma \\
\hline 15 & Butea monosperma & Casearia tomentosa & Casearia tomentosa \\
\hline 16 & Casearia tomentosa & Cassia fistula & Cassia fistula \\
\hline 17 & Cassia fistula & Cochlospermum religiosum & Cochlospermum religiosum \\
\hline 18 & Cochlospermum religiosum & Dalbergia sissoo & Dalbergia sissoo \\
\hline 19 & Dalbergia sissoo & Diospyrous melanoxylon & Diospyrous melanoxylon \\
\hline 20 & Diospyrous melanoxylon & Emblica officinalis & Emblica officinalis \\
\hline 21 & Emblica officinalis & Feronia limonia & Erythrina suberosa \\
\hline 22 & Elaceodendron glaucum & Gardenia turgid & Feronia limonia \\
\hline 23 & Eugenia heymeanum & Grewia tilaefolia & Ficus glomerata \\
\hline 24 & Feronia limonia & Holarrhena antidysentrica & Grewia tilaefolia \\
\hline 25 & Ficus religiosa & Holoptelia integrifolia & Holarrhena antidysentrica \\
\hline
\end{tabular}


Table Continued

\begin{tabular}{llll}
\hline S No & Lalitpur-Chitrakoot forest & Chitrakoot-Mahoba forest & Lalitpur-Mahoba forest \\
\hline 26 & Grewia tilaefolia & Lagerstromia parviflora & Holoptelia integrifolia \\
27 & Holarrhena antidysentrica & Lannea coromandelica & Lagerstromia parviflora \\
28 & Holoptelia integrifolia & Madhuca indica & Lannea coromandelica \\
29 & Lagerstromia parviflora & Mangifera indica & Madhuca indica \\
30 & Lannea coromandelica & Miliusa tomentosa & Miliusa tomentosa \\
31 & Madhuca indica & Mitragyna parviflora & Mitragyna parviflora \\
32 & Miliusa tomentosa & Pongamia pinnata & Pongamia pinnata \\
33 & Mitragyna parviflora & Pterocarpus marsupium & Prosopis spicigera \\
34 & Ougeinia oojeinensis & Sterculia urens & Pterocarpus marsupium \\
35 & Pongamia pinnata & Syzygium cuminii & Schleichera oleosa \\
36 & Pterocarpus marsupium & Tectona grandis & Sterculia urens \\
37 & Sterculia urens & Terminalia arjuna & Syzygium cuminii \\
38 & Syzygium cuminii & Terminalia bellerica & Tamarindus indica \\
39 & Tectona grandis & Terminalia chebula & Tectona grandis \\
40 & Terminalia arjuna & Terminalia tomentosa & Terminalia arjuna \\
41 & Terminalia bellerica & Zizyphus xylopyra & Terminalia bellerica \\
42 & Terminalia chebula & & Terminalia chebula \\
43 & Terminalia tomentosa & Terminalia tomentosa \\
44 & Zizyphus xylopyra & Wrightia tomentosa \\
45 & & Zizyphus xylopyra \\
\hline
\end{tabular}

Table 6 Common Herbs/shrubs/Climbers species of three forest communities

\begin{tabular}{llll}
\hline S No & Lalitpur-Chitrakoot forest & Chitrakoot-Mahoba forest & Lalitpur-Mahoba forest \\
\hline 1 & Aloe barbadensis & Aloe barbadensis & Aloe barbadensis \\
2 & Andrographis paniculata & Andrographis paniculata & Andrographis paniculata \\
3 & Asparagus racemosus & Asparagus racemosus & Asparagus racemosus \\
4 & Boerhavia diffusa & Caesalpinia dicapetala & Balanites aegyptica \\
5 & Butea superb & Calotropis procera & Caesalpinia dicapetala \\
6 & Caesalpinia dicapetala & Capparis deciduas & Calotropis procera \\
7 & Calotropis procera & Cocculus hirsutus & Capparis deciduas \\
8 & Capparis decidua & Convolvulus microphullus & Cocculus hirsutus \\
9 & Carissa spinarum & Curcuma amada & Convolvulus microphullus \\
10 & Centella asiatica & Datura alba & Curcuma amada \\
11 & Cocculus hirsutus & Dendrocalamus strictus & Datura alba \\
12 & Convolvulus microphullus & Echinops echinatus & Dendrocalamus strictus \\
13 & Curcuma amada & Flacourtia indica & Echinops echinatus \\
14 & Datura alba & Gymnma sylvestre & Flacourtia indica \\
15 & Dendrocalamus strictus & Helicteres isora & Gymnma sylvestre \\
16 & Echinops echinatus & Ichnocarpus frutescens & Helicteres isora \\
17 & Flacourtia indica & Lantana camara & Ichnocarpus frutescens \\
\hline
\end{tabular}




\begin{tabular}{|c|c|c|c|}
\hline S No & Lalitpur-Chitrakoot forest & Chitrakoot-Mahoba forest & Lalitpur-Mahoba forest \\
\hline 18 & Grewia hirsute & Ocimum basilicum & Lantana camara \\
\hline 19 & Gymnma sylvestre & Opuntia dilloni & Ocimum basilicum \\
\hline 20 & Helicteres isora & Piper longum & Opuntia dilloni \\
\hline 21 & Hemidesmus indicus & Rauwolfia serpentina & Piper longum \\
\hline 22 & Ichnocarpus frutescens & Solanum indicum & Rauwolfia serpentina \\
\hline 23 & Lantana camara & Tinospora cardifolia & Solanum indicum \\
\hline 24 & Mimosa himalayana & Vitex nigundo & Tinospora cardifolia \\
\hline 25 & Nyctanthes Arbortristis & Withania somnifera & Vitex nigundo \\
\hline 26 & Ocimum basilicum & Woodfordia fruticosa & Withania somnifera \\
\hline 27 & Operculina turpenthus & Zizyphus mauritiana & Woodfordia fruticosa \\
\hline 28 & Opuntia dilloni & Zizyphus nummularia & Zizyphus mauritiana \\
\hline 29 & Piper longum & Zizyphus oenoplia & Zizyphus nummularia \\
\hline 30 & Rauwolfia serpentina & & Zizyphus oenoplia \\
\hline 31 & Solanum indicum & & \\
\hline 32 & Tinospora cardifolia & & \\
\hline 33 & Vitex nigundo & & \\
\hline 34 & Withania somnifera & & \\
\hline 35 & Woodfordia fruticosa & & \\
\hline 36 & Zizyphus mauritiana & & \\
\hline 37 & Zizyphus nummularia & & \\
\hline 38 & Zizyphus oenoplia & & \\
\hline
\end{tabular}

Table 7 Similarity(\%) of tree species between three forest communities

\begin{tabular}{lll}
\hline Forest communities & $\begin{array}{l}\text { Number of } \\
\text { common tree } \\
\text { species }\end{array}$ & Similarity (\%) \\
\hline Lalitpur vs Chitrakoot forest & 44 & 77.19 \\
Chitrakoot vs Mahoba forest & 41 & 78.84 \\
Lalitpur vs Mahoba forest & 45 & 81.81 \\
\hline
\end{tabular}

Table 8 Similarity(\%) of shrubs/herbs/climbers species between three forest communities

\begin{tabular}{lll}
\hline Forest communities & $\begin{array}{l}\text { Number of } \\
\text { Common Shrubs/ } \\
\text { Herbs/Climbers } \\
\text { species }\end{array}$ & Similarity (\%) \\
\hline Lalitpur vs Chitrakoot forest & 38 & 97.43 \\
Chitrakoot vs Mahoba forest & 29 & 84.05 \\
Lalitpur vs Mahoba forest & 30 & 84.5 \\
\hline
\end{tabular}

\section{Conclusions}

At present, the biodiversity of Bundelkhand region are declining fast due to the degradation of habitats by heckles and indiscriminate cutting of forests for timber, fuel wood, and expansion of agriculture, construction of roads, querying of stones, grazing, invasion of alien weeds, over exploitation of plants for medicines etc., the rich biodiversity of Bundelkhand region has reduced to a great extent. Tropical dry deciduous forests are enriched with economically important species. Vegetation composition, diversity of species and their habitats are well understood for other tropical forest types and compared also to dry deciduous forests. Dry deciduous forests are among the most exploited and endangered ecosystems of the biosphere. The present study will serve as a primary input towards monitoring and sustaining the phyto-diversity of tropical dry deciduous forests in the state of Uttar Pradesh as well as other part of the world having similar kind of forest areas. The high species diversity and low basal cover in miscellaneous forest clearly indicate the growing nature of this forest types with maximum number of species having younger individuals. Study on floristic composition and diversity will be useful to the conservation researchers and scientists and also to the forest managers for effective management of the forest ecosystem.

The mixed forests are not adequately stocked. Due to drier conditions prevailing, the forests are open and poor in growth. Due to over increasing biotic interference like recurring fires, unrestricted heavy grazing, over exploitation and indiscriminate felling under nectar, fast retrogression has set in the forests, tree growth is winding down at an alarming speed.

\section{Funding}

None. 


\section{Acknowledgments}

Authors are thankful to DFOs and staff of respective District Forest Department, Government of Uttar Pradesh, India and village persons who help us during the survey and plant identification, etc.

\section{Conflicts of interest}

The author declares there are no conflicts of interest.

\section{References}

1. Anderson Teixeira KJ, Miller AD, Mohan JE, et al. Altered dynamics of forest recovery under a changing climate. Glob Chang Biol. 2013;19(7):2001-2021.

2. Godfray HC. Ecology. Food and biodiversity. Science. 2011;333(6047):1231-1232.

3. Rai PK. Assessment of multifaceted environmental issues and model development of an Indo-Burma hotspot region. Environ Monit Assess. 2012;184(1):113-131.

4. Champion HG, Seth SK. A revised survey of the Forest Type of India. Manager of Publications Govt. of India, New Delhi. 1968.

5. Murphy PG, Lugo AE. Ecology of Tropical Dry Forest. Ann Rev Ecol Syst. 1986;17:67-88.

6. Cottam G, Curtis JT. The Use of Distance Measures in Phytosociological Sampling. Ecology. 1956;37(3):451-460.

7. Simpson EH. Measurement of diversity. Nature. 1949;163:688.

8. Shannon CE. The mathematical theory of communication. Bell System Technical Journal Banner. 1948;27(3):379-423.

9. Sorenson T. A method of establishing group of equal amplitude in plant society based on similarity of species content. K Kanske Vidensk Selsk Bioi Skr. 1948;5(4):1-34.

10. Verma MK, Niranjan RK, Pal A. Vegetational structures and species diversity a tropical dry deciduous forest of Uttar Pradesh, India. Indian Forester 2015;141(7):789-797.

11. Verma MK, Niranjan RK, Pal A. Floristic composition and vegetation types in a tropical dry deciduous forest of Chitrakoot, Bundelkhand region of Uttar Pradesh, India. Indian Journal of Tropical Biodiversity. 2013;21(1-2):15-27.

12. Verma MK, Niranjan RK, Pal A. Phytosociological attributes of a tropical dry deciduous forest of Bundelkhand region of Uttar Pradesh, India. Journal of Biodiversity and Environmental Sciences. 2013;3(10):86-99.

13. Rao SVS, Mishra RM. Phytosociological analysis of two tropical deciduous forests of central India. J of Tropical Forestry. 1994;10(4):278286.

14. Devi SL, Yadav PS. Floristic diversity assessment and vegetation analysis of tropical semi-evergreen forest of Manipur, north east India. Tropical Ecology. 2006;4(7):89-98.

15. Parthasarathy N, Karthikeyan R. Biodiversity and population density of woody species in a tropical evergreen forest in Courtallum reserve forest, Western Ghats, India. Tropical Ecology. 1997;38(2):297-306.

16. Tripathi KP, Mehrotra S, Pushpangadan P. Vegetation characteristics of tropical forest of Andaman Islands. Indian Forester. 2006;132(2):165180.

17. Yadav RK, Yadav AS. Vascular Flora of Bala-Fort Forest in Alwar, Rajasthan. The Indian Forester. 2006;132(2):233-238.
18. Rawat GS, Bhainsora NS. Woody vegetation of Shivaliks and outer Himalaya in north western India. Tropical Ecology. 1999;40(1):119-128.

19. Okali DUU, Ola Adams BA. Tree population changes in treated rainforest at Omo forest reserve, south-western Nigeria. Journal of Tropical Ecology. 1987;3(4):291-313.

20. Swaine MD, Hall JB, Alexander CJ. Tree population dynamics at Kade, Ghana (1968-1982). J Trop Ecol. 1987;3(4):331-345.

21. Elourad C, Pascal JP, Pelissier R, et al. Monitoring the structure and dynamics of a dense moist evergreen forest in the western Ghats (Kudagu District, Karnataka, India). Tropical Ecology. 1997;38(2):193-214.

22. Kadavul K, Parthasarathy N. Structure and composition of wood species in tropical semi-evergreen forest of Kalrayan hills, eastern ghat, India. Tropical Ecology. 1999;40(2):247-260.

23. Nicholson DI. A study of virgin forest near Sandakan North Borneo. In:Pmc. Symp. on ecological research in humid tropics vegetation. Kuching: UNESCO. Government of Sarawak. 1965;67-86.

24. Proctor J, Lee YF, Langley AM, et al. Ecological studies on Gunung Silam, a small ultrabasic mountain Sabah, Malaysia. Journal of Ecology. 1988;76(2):455-463.

25. Manokamn N, Kochummen KM. Recruitment, growth and mortality of tree species in a lowland dipetrocarp forest in Peninsular Malaysia. J Trop Ecol. 1987;3(4):315-330.

26. Campbell DG, Stone JL, Rosas Jr A. A comparison of the phytosociology and dynamics of three foodplain (Várzea) forests of known ages, Rio Jurua, western Brazilian Amazon. Botanical Journal of Linnean Society. 1992;108(3):213-237.

27. Valencia R, Balslev H, Mino GCPY. High tree alpha-diversity in Amazonian Ecuador. Biodiversity and Conservation. 1994;3(1):21-28.

28. Tripathi KP, Tripathi S, Selven T, et al. Community structure and species diversity of saddle peak forests in Andaman Island. Tropical Ecology. 2004;45(2):241-250.

29. Strasberg D. Diversity, size composition and spatial aggregation among trees on a 1 ha rain forest plot at La Reunion. Biodiversity and Conservation. 1996;5(7):825-840.

30. Singh L, Singh JS. Species structure, dry matter dynamics and carbon flux of a dry tropical forest in India. Annals of Botany. 1991;68(3):263-273.

31. Mishra RK, Upadhyay VP, Mohanty RC. Vegetation Ecology of the Similipal Biosphere Reserve, Orissa, India. Applied Ecology and Environmental Research. 2008;6(2):89-99.

32. Venkateshwaran R, Parthasarathy N. Tree dry evergreen forests on the Coromandel Coast of India: structure, composition and human disturbance. Ecotropica. 2003;9:45-58.

33. Mani S, Parthasarathy N. Biodiversity assessment of trees in five inland tropical dry evergreen forests of peninsular India. Systematics and Biodiversity. 2005;3(1):1-12.

34. Reddy CS, Babar S, Giriraj A, et al. Structure and floristic composition of tree diversity in tropical dry deciduous forest of Estern Ghats, Southern Andhra Pradesh, India. Asian Journal of Scientific Research. 2008;1(1):57-64.

35. Parthasarathy N. Tree diversity and distribution in undisturbed and human-impacted sites of tropical wet evergreen forest in southern Western Ghats, India. Biodiversity and Conservation. 1999;8(10):1365-1381.

36. Tripathi KP, Singh B. Species diversity and vegetation structure across various strata in natural and plantation forests in Katernia ghat Wildlife Sanctuary, North India. Tropical Ecology. 2009;50(1):191-200. 
37. Murali KS, Uma S, Shaanker U, et al. Extraction of forest products in the forests of Biligirirangan Hills, India and impact of NTFP extraction on regeneration, population structure and species composition. Economic Botany. 1996;50(3):252-269.

38. Sundarapandian SM, Swamy PS. Plant biodiversity at Low-Elevation Evergreen and Moist Deciduous Forests at Kodayar (Western Ghats, India). International Journal of Ecology and Environmental Sciences. 1997;23:363-379.

39. Ghate U, Joshi NV, Gadgil M. On the patterns of tree diversity in the Western Ghats of India. Current Science. 1998;75(6):594-603.

40. Singh JS, Singh SP, Saxena AK, et al. The forest vegetation of Silent Valley. In Tropical Rain Forests - The Leeds Symposium. 1984;25-52.

41. Ganesh T, Ganesan R, Devy MS, et al. Assessment of plant biodiversity at a mid-elevation evergreen forest of Kalakad-Mundan thura. Tiger reserve, Western Ghats, India. Current Science. 1996;71(5):379-392.

42. Chittibabu CV, Parthasarathy N. Attenuated tree species diversity in human-impacted tropical evergreen forest sites at Kolli hills, Eastern Ghats, India. Biodiversity and Conservation. 2000;9(11):1493-1519.

43. Jha CS, Singh JS. Composition and dynamics of dry tropical Forest in relation to soil texture. Journal of Vegetation Science. 1990;1(5):609614.

44. Varghese AO, Menon ARR. Ecological niches and amplitudes of rare, threatened and endemic trees of Peppara Wildlife Sanctuary. Current Science. 1999;76(9):1204-1208.

45. Shrestha KK, Jha PK. Plant diversity and evaluation of conservation measures in the Royal Bardia National Park (RBNP). A report submitted to World Wildlife Fund Nepal Program. Kathmandu, Nepal. 1997.

46. Pandey SK, Shukla RP. Plant diversity in managed sal (Shorea robusta Gaertn.) forests of Gorakhpur, India: species composition, regeneration and conservation. Biodiversity and Conservation. 2003;12(11):22952319.

47. Rautiainen O. Spatial yield model for Shorea robusta in Nepal. Forest Ecology and Management. 1999;119(1-3):151-162.

48. Swan Jr FR. Tree distribution patterns in the Bukittimah nature reserve, Singapore. Garden Bulleten of Singapore. 1988;41(2):59-81.

49. Heaney A, Proctor J. Preliminary studies on forest structure and floristics on Volcan Barva, Costa Rica. J Trop Ecol. 1990;6(3):307-320.

50. Visalakshi N. Vegetation analysis of two tropical dry evergreen forest in Southern India. Tropical Ecology. 1995;36(1):117-127.

51. Supriya DL, Yadava PS. Floristic diversity assessment and vegetation analysis of tropical semievergreen forest of Manipur, north east India. Tropical Ecology. 2006;47(1):89-98.

52. Campbell DG, Daly DC, Prance GT, et al. Quantitative ecological inventory of Terra firma and the Varzea tropical forest on the Rio Xingu, Brazilian Amazon. Brittanica. 1986;38:369-393.

53. Proctor J, Andan JM, Chai P, et al. Ecological studies in four contrasting lowland rain forests in Gunung Mulu National Park, Sarawak I. Forest environment, structure, and floristics. J. Ecol.1983;71(1):237-260.

54. Richards PW. The Tropical Rain Forest: An Ecological Study, 2nd edition. Cambridge: Cambridge University Press. 1996.

55. Pascal JP, Pelissier R. Structure and floristic composition of a tropical evergreen forest in southwest India. Journal of Tropical Ecology. 1996;12(2):191-214

56. Upadhaya K, Pandey HN, Law PS, et al. Diversity and population characteristics of woody species in sub-tropical humid forest exposed to cultural disturbances in Meghalaya, North-east India. Tropical Ecology 2004;45(2):303-314.

57. Jamir SA, Pandey HN. Vascular plant diversity in the sacred groves of Jaintia Hills in north-east India. Biodiversity and Conservation. 2003;12(7):1497-1510.

58. Boom B. A forest inventory in Amazonian Bolivia. Biotropica. 1986;18(4):287-294.

59. Johnston M, Gilman M. Tree population in low diversity forest, Guayana. I.floristic composition and stand structure. Biodiversity and conservation. 1995;4(4):339-362.

60. Debel CV, Day FP. Structural composition of four plant communities in the Great Dismal Swamp, Verginia. Bulletin Theory Botanical Club. 1977;104(4):434-455.

61. Saxena AK, Singh JS. A phyto-sociological analysis of woody species in forest communities of a part of Kumaun Himalaya. Vegetatio. 1982;50(1):3-22.

62. Ralhan PK, Saxena AK, Singh JS. Analysis of forest vegetation at and around Nainital in Kumaun Himalaya. Proceedings of Indian National Science Academy. 1982;48(1):121-137.

63. Pande PK, Negi JDS, Sharma SC. Plant species diversity and vegetation analysis in moist temperate Himalayan Forest. Abstracted in First Indian Ecological Congress, New Delhi. 1996.

64. Pande PK. Comparative vegetation analysis and sal (Shorea robusta) regeneration in relation to their disturbance magnitude in some sal forests. Tropical Ecology. 1999;40(1):51-61.

65. Mc Nanghton SJ. Relationship among functional properties of California grassland. Nature. 1967;216:168-169.

66. Monk CD. Tree species diversity in the eastern deciduous forest with special reference to North Central Florida. American Naturalist. 1967;101(9):173-187.

67. Risser PG, Rice EI. Diversity in tree species in Oklahoma upland forests. Ecology. 1971;52(5):876-880.

68. Singhal RM, Rawat VRS, Kumar P, et al. Vegetation analysis of woody species of some forest of Chakarata Himalaya, India. Indian Forester. 1986;112(9):819-823.

69. Knight DH. A physiological analysis of species rich tropical forest on Barro Colorado Island, Panama. Ecological Monograph. 1975;45(3):259 289.

70. Rout SK, Gupta SR. Analysis of Morvi Hills, North-East Haryana. Proc Indian Acad Sci. 1989;99(2):117-125.

71. Singhal RM, Sharma SD. Phytosociological analysis of tropical forest in Doon Valley of U.P. Journal of Tropical Forestry. 1989;5:57-65.

72. Dani HP, Pati DP, Basu S, et al. Phytosociological analysis of forest vegetation of Kantamal region Phulbani, Orissa. J Tropical Forestry. $1991 ; 7: 151-158$

73. Panchal NS, Pandey AN. Analysis of vegetation of Rampara forest in Saurashtra region of Gujarat state of India. Tropical Ecology. 2004;45(2):223-231

74. Prasad R, RK Pandey. An observation on plant diversity of sal and teak forests in relation to intensity of biotic impact at various distances from habitation in Madhya Pradesh : A case study. J of Tropical Forestry. 1992;8(1):62-83.

75. Connell JH, Orias E. The ecological regulation of species diversity. Amer Nature. 98(90):399-414 
76. Odum EP. Fundamentals of Ecology. WB Saunders Co. Philadelphia. 1971.

77. Keel SHK, Prance GT. Studies of the vegetation of a white sand black water ipago (Rio Negro, Brazil). Acta Amazonica. 1979;9(4):645-655.

78. Jacob-Marius. The tropical rain forest. Springer-Verlag, New York. 1987.

79. Parthasarathy N, Karthikeyan R. Plant biodiversity inventory and conservation of two tropical dry evergreen forests on the Coromandel coast, south India. Biodiversity and Conservation. 1997;6(8):1063-1083.
80. Hubbell SP, Foster RB. Diversity of canopy tree in a neotropical forest and implications for conservation. In: Sutton SL, Whitmore TC, et al Editors. The Tropical Rain Forest: Ecology and Management Blackwell, Oxford. 1983.

81. Hubbell SP. Tree dispersion, abundance and diversity in a tropical dry forest. Science. 1979;203(4387):1299-1309.

82. Connell JH. Diversity in tropical rain forest and coral reefs. Science. 1978;199(4335):1302-1310. 